\title{
Implementasi Informasi Portofolio Pada Marketplace Grafis Tradisional (Gambar Tangan)
}

\author{
Nofiyati, Dadang Iskandar, Zikri Kurniawan \\ Fakultas Teknik, Informatika, Universitas Jenderal Soedirman, Purwokerto, Indonesia \\ Email: ${ }^{1}$ nofiyati@unsoed.ac.id, ${ }^{2}$ dadang.iskandar@ unsoed.ac.id, ${ }^{3}$ zikri.kurniawan@ unsoed.ac.id \\ Email Penulis Korespondensi: nofiyati@unsoed.ac.id
}

\begin{abstract}
Abstrak-Kemajuan teknologi informasi saat ini sangat berpengaruh dalam berbagai bidang kehidupan seperti pendidikan, ekonomi, dan sosial. Masyarakat dituntut untuk bisa memanfaatkan teknologi informasi dalam menunjang aktifitasnya dengan memanfaatkan website sebagai media digital untuk bisa menjangkau pemasaran yang lebih luas melalui media online. Komunitas Kreator grafis tradisional Krigan Purwokerto saat ini masih melakukan transaksi jual beli karya dan memajang karyanya secara manual sehingga dibutuhkan adanya sistem yang mampu menyediakan wadah bagi Kreator untuk memajang karyanya dan sekaligus mampu menangani proses transaksi jual beli karya antara Kreator dengan Klien. Tujuan dari penelitian ini adalah mengimplementasikan informasi portofolio pada marketplace khususnya para kreator grafis tradisional (gambar tangan) untuk dapat menjangkau pemasaran lebih luas dan membangun brand dengan menyediakan informasi portofolio Kreator. Metode yang digunakan pada penelitian ini adalah metode waterfall serta menggunakan bahasa pemrograman PHP dan basis data MySQL. Implikasi hasil dari pengimplementasian informasi portofolio pada marketplace kreator grafis tradisional ini dapat meningkatkan nilai dan rating kreator terbukti dengan peningkatan jumlah follower dan juga dapat merekomendasikan karyanya ke calon pembeli dalam proses transaksi karya Kreator grafis tradisional.
\end{abstract}

Kata Kunci: Implementasi, Portofolio, Marketplace, Grafis Tradisional, Waterfall

\begin{abstract}
Advances in information technology are currently very influential in various fields of life, such as education, economics, and social. The public is demands to be able to use information technology to support their activities by utilizing websites as digital media to be able to reach wider marketing through online media. The traditional graphic creators community of Krigan Purwokerto is currently still doing buying and selling works and displaying their works manually so need a system is able to provide the place for creators to display their works and at the same time be able to handle the process of buying and selling works between creators and clients. The purpose of this research is to make portfolio information in the marketplaces especially traditional graphic creators (hand drawings) to be able to reach wider marketing and build brand by providing Creator portfolio information. The method used in this research is the waterfall method and using the PHP programming language and MySQL database. To involve the results of implementing portfolio information in the traditional graphic creator marketplace can increase the creator's value and rating as showed by an increase in the number of followers and can also recommend his work to prospective buyers in the transaction process of traditional graphic creator works.
\end{abstract}

Keywords: Implementation, Portfolio, Marketplace, Traditional Graphic, Waterfall

\section{PENDAHULUAN}

Perkembangan di bidang teknologi informasi sekarang ini telah mengalami kemajuan secara pesat, hal ini tidak terlepas dari keberadaan internet. Teknologi internet telah banyak dimanfaatkan oleh masyarakat sebagai sarana yang dapat membantu dalam segala aspek kehidupan, salah satunya dalam dunia bisnis. Teknologi internet ini telah membuat sebuah gerbang baru bagi usaha/bisnis saat ini dimana semua orang di dunia dapat berkomunikasi dan berbisnis tanpa dibatasi oleh jarak dan waktu. Bisnis dapat go international hanya dengan membuat situs web untuk berkomunikasi dalam pemasaran melalui online channel. Melalui pemasaran online para pelaku usaha dapat melakukan promosi secara online dan memasarkan produknya sehingga potensi pasar yang masih sangat luas dapat dijangkau.

Salah satu media pemasaran online adalah marketplace yang merupakan sebuah sistem informasi antar organisasi dimana pembeli dan penjual dapat mengkomunikasikan informasi tentang harga, produk dan mampu menyelesaikan transaksi melalui saluran komunikasi elektronik. Marketplace merupakan model bisnis baru yang berkembang seiring pesatnya perkembangan infrastruktur teknologi informasi. Marketplace ini dirancang untuk meminimalisir proses bisnis yang kompleks sehingga tercipta efisiensi dan efektifitas. Dengan adanya marketplace tersebut setiap orang dapat melakukan aktivitas jual beli dengan mudah, cepat dan murah karena tidak ada batas ruang, jarak dan waktu. Marketplace merupakan platform transaksi bisnis online yang menyediakan metode elektrik untuk memfasilitasi transaksi komersil seperti menjual barang, jasa ataupun informasi secara online antara pembeli dan penjual [1].

Pemanfaatan teknologi informasi saat ini sudah mulai merambah industri kreatif. Dalam industri kreatif khususnya peranan teknologi informasi menjadi dominan dalam menghasilkan karya kreatif [2]. Di era digital saat ini dalam memperkenalkan hasil industri kreatif setiap kelompok atau individu tentu diperlukan media agar suatu karyanya dapat diketahui dan dipasarkan secara luas untuk mendapatkan hasil yang maksimal. Salah satu pemanfaatannya adalah dengan adanya website khusus yang dapat menjadi wadah portofolio bagi para pelaku kreatif untuk memajang karya mereka. Bagi para pelaku kreatif, khususnya pelaku kreatif dibidang grafis, portofolio merupakan suatu keharusan. 
Dalam industri kreatif, portofolio memegang peranan yang jauh lebih penting [3]. Melalui portofolio, para klien dapat menilai kemampuan dan karakteristik dari karya pelaku kreatif sehingga pelaku kreatif memiliki brand yang dapat dikenal oleh klien. Saat ini para pelaku kreatif dituntut untuk memiliki portofolio semenarik mungkin. Portofolio merupakan salah satu hal yang paling penting karena memiliki sejumlah manfaat yang dibawa portofolio yaitu dapat membantu dalam memamerkan karya secara online, menarik klien baru dan membangun eksposur online yang kuat dan luas terhadap hasil karya para kreator grafis.

Dari penelitian sebelumnya yang dilakukan oleh Yustiani dan Rio [4] yang menyatakan bahwa dibalik segudang manfaat yang diberikan oleh marketplace terdapat kekurangan yang harus segera dicari solusinya. Dalam marketplace para pelaku usaha maupun bisnis tidak dapat membangun citra perusahaan mereka, karena di marketplace tersebut para pengunjung tidak begitu peduli dengan nama produk ataupun brand. Sedangkan dalam buku Studi Industri Kreatif Indonesia disebutkan bahwa sejauh ini belum banyak pelaku kreatif yang menjalankan e-commerce secara lengkap. Biasanya para pelaku kreatif hanya memiliki halaman situs internet perusahaannya, yang hanya berfungsi memperkenalkan produk atau promosi produk, tanpa adanya transaksi online [5].

Di bidang grafis sendiri, sudah banyak website yang menjadi pilihan utama bagi kreator untuk memajang karya-karyanya, seperti www.behance.net yang dimiliki oleh Adobe System. Akan tetapi website tersebut hanya berfokus pada karya grafis digital. Untuk dapat membantu para kreator grafis tradisional dalam membangun brand dan melakukan transaksi terhadap hasil karyanya dibutuhkan adanya suatu teknologi digital yang mampu menjadi wadah portofolio dan marketplace bagi para kreator grafis tradisional dalam memajang karya mereka, yang sekaligus mampu menangani proses transaksi jual beli karya antara kreator dengan klien melalui sistem online. Dengan adanya implementasi informasi portofolio pada marketplace karya grafis tradisional ini diharapkan dapat memanfaatkan marketplace secara maksimal dan dapat membangun brand sehingga apresiasi terhadap karya-karya pelaku kreatif gambar tradisional dapat meningkat dan dapat berkembang kearah yang lebih baik.

\section{METODOLOGI PENELITIAN}

\subsection{Tahapan Penelitian}

Penelitian ini menggunakan metodologi SDLC (Sistem Development Life Cycle) yang merupakan metodologi dalam pengembangan sebuah sistem dengan menggunakan model pengembangan sistem waterfall. Tahap awal dari tahapan penelitian ini adalah mendapatkan data dengan cara wawancara kepada anggota komunitas kreator grafis tradisional yaitu Krigan Purwokerto untuk mendapatkan data tentang komunitas kreator grafis tradisional serta mengetahui proses bisnisnya. Selain itu dilakukan juga studi literatur baik melalui buku, paper, jurnal dan penelitian terkait, yang dipergunakan sebagai referensi dalam melakukan penelitian ini. Tahapan dalam penelitian ini dapat ditunjukkan dalam Gambar 1.

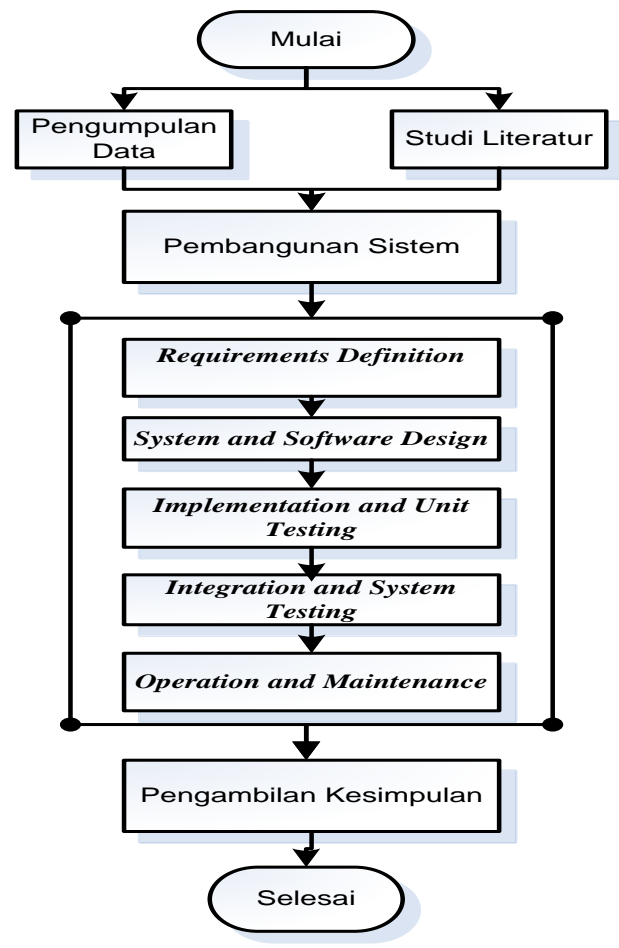

Gambar 1. Tahapan Penelitian 


\subsection{Metode Pengembangan Sistem}

Metode pengembangan sistem yang dilaksanakan pada penelitian ini adalah dengan menggunakan metode waterfall. Metode waterfall menurut Pressman [14] terdapat 5 tahapan, yaitu tahap requirements definition (analisis kebutuhan), system and software design (desain sistem), implementation and unit testing (penulisan kode program), integration and system testing (pengujian sistem), dan operation and maintenance (penerapan dan pemeliharaan). Tahapan metode waterfall dapat ditunjukkan pada Gambar 2.

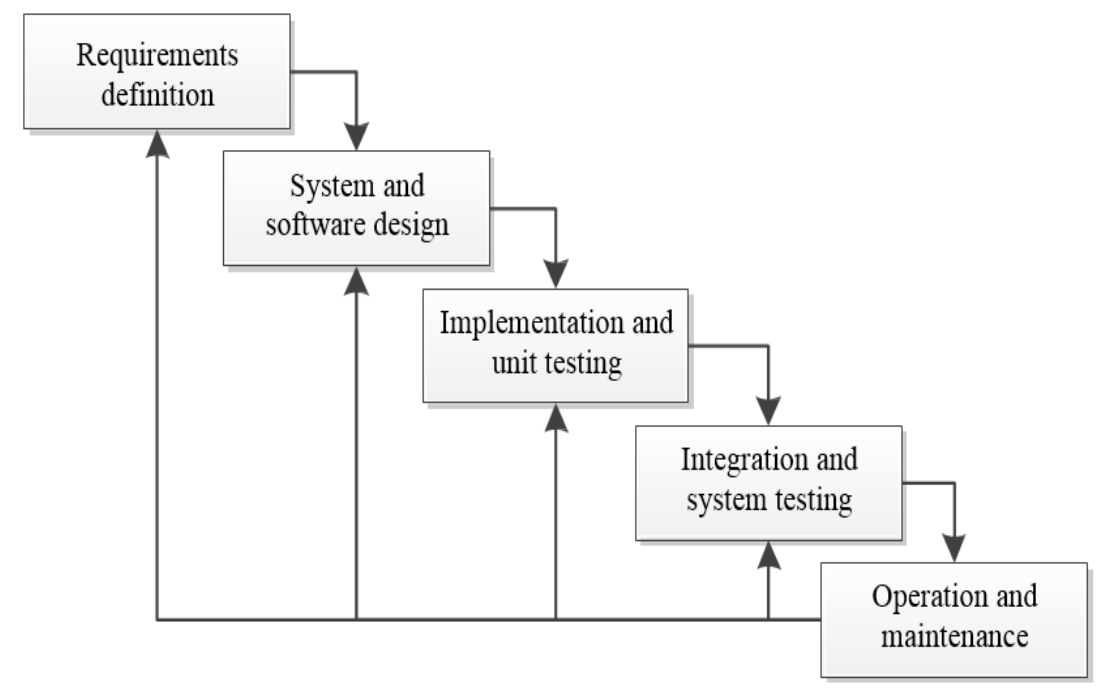

Gambar 2. Tahapan metode Waterfall [14]

\section{a. Tahap Requirements Definition}

Tahap requirements definition atau analisis kebutuhan merupakan tahap pertama yang menjadi dasar proses pembuatan sistem. Tahap analisa dilakukan dengan cara studi literatur, wawancara kepada salah satu kreator anggota komunitas Krigan Purwokerto dan pengumpulan data mengenai grafis tradisional. Setelah dilakukan analisis terhadap spesifikasi kebutuhan dari komunitas Krigan ini maka akan terbentuk kebutuhan-kebutuhan pengguna atau user requirement yang dapat memenuhi kebutuhan informasi portofolio pada sistem marketplace grafis tradisional.

\section{b. Tahap System and Software Design}

Tahap system and software design atau desain sistem merupakan tahap penyusunan proses, data, aliran proses dan hubungan antar data yang paling optimal untuk menjalankan proses dan memenuhi kebutuhan pengguna sesuai dengan hasil analisa kebutuhan. Pada tahap ini akan menghasilkan dua desain, yaitu desain data dan desain antarmuka. Desain data akan menghasilkan Data Flow Diagram (DFD) dan Entity Relationship Diagram (ERD), sedangkan desain antarmuka akan menghasilkan antarmuka yang akan diimplementasikan ke sistem portofolio pada marketplace grafis tradisional.

\section{c. Tahap Implementation and Unit Testing}

Tahap implementation and unit testing atau penulisan kode program merupakan tahap penerjemahan desain sistem yang telah dibuat ke dalam bentuk perintah-perintah yang dimengerti komputer menggunakan bahasa pemrograman dan basis data tertentu. Tahap ini merupakan implementasi dari tahap desain sistem yangtelah dibuat sebelumnya untuk dapat diterjemahkan ke dalam bahasa pemrograman yang kemudian diuji untuk memastikan sistem dapat berjalan dengan baik. Sistem portofolio pada marketplace ini menggunakan bahasa pemrograman PHP dan basis data MySQL.

\section{d. Tahap Integration and System Testing}

Tahap integration and system testing atau pengujian sistem merupakan tahap untuk menguji sistem yang dibuat untuk mengetahui kekurangan pada sistem sebelum digunakan. Pengujian ini dilakukan oleh pembuat sistem dan pengguna sistem. Pengujian dilakukan dengan dua metode yaitu pengujian blackbox dan pengujian sistem dengan Mean Opinion Score (MOS) berdasarkan user acceptance test terhadap responden terkait sistem yang telah dibangun.

\section{e. Tahap Operation and Maintenance}

Tahap operation and maintenance atau penerapan dan pemeliharaan merupakan tahap menerapkan sistem yang telah dibuat dan diuji ke komunitas grafis tradisional. Pemeliharaan dilakukan agar penggunaan dari sistem portofolio pada marketplace dapat terus optimal dan meminimalisir kegagalan pada sistem portofolio pada marketplace grafis tradisional. 


\section{HASIL DAN PEMBAHASAN}

\subsection{Analisis Kebutuhan}

Untuk mengetahui kebutuhan sistem yang dibangun, maka dilakukan pengumpulan data dengan metode wawancara yang dilakukan ke salah satu komunitas grafis tradisional, yaitu Krigan Purwokerto. Data dan informasi yang diperoleh kemudian dijadikan pedoman dalam merancang dan membangun sistem yang akan dibuat. Pengelolaan data yang sebelumnya dilakukan pada komunitas ini masih dilakukan secara manual sehingga diperlukan adanya pengelolaan data secara online dan terkomputerisasi dikarenakan jumlah anggotanya yang semakin banyak dan kebutuhan persebaran informasi yang semakin meluas.

Selanjutnya untuk mengimplementasikan informasi portofolio pada marketplace dilakukan studi pustaka dan menganalisa kebutuhan yang mendukung informasi portofolio. Hal ini berkaitan dengan analisis desain informasi portofolio yang menarik, fitur untuk memajang karya, dan fitur brand sehingga klien dapat menilai kemampuan dan karakteristik karya dari kreator. Hasil analisis ini diimplementasikan dalam tahap implementation and unit testing yang dibahas dalam implemetasi.

Setelah melaksanakan kegiatan tersebut diatas, maka dapat ditentukan kebutuhan fungsional dan nonfungsional sesuai dengan informasi portofolio pada marketplace komunitas grafis tradisional. Berdasarkan analisis yang telah dilakukan, maka kebutuhan dibagi menjadi berikut ini.

\section{a. Kebutuhan Fungsional}

Kebutuhan Fungsional berfungsi untuk menggambarkan fungsionalitas sistem atau layanan-layanan sistem. Dengan kebutuhan fungsional, dapat diketahui kebutuhan sistem yang harus disediakan, bagaimana sistem bereaksi terhadap input tertentu, dan bagaimana perilaku sistem pada situasi tertentu. Pada sistem ini terdapat 3 (tiga) pengguna. Berikut ini adalah identifikasi pengguna dalam implementasi informasi portofolio pada marketplace grafis tradisional antara lain :

1. Administrator, yang merupakan pelaku bidang grafis tradisional (gambar tangan) yang

berkompeten sekaligus pengelola sistem.

2. Keator, yang merupakan para pembuat karya grafis tradisional (gambar tangan).

3. Klien, yang merupakan para pencari karya grafis tradisional (gambar tangan).

Berdasarkan hasil identifikasi pengguna maka dapat diidentifikasi kebutuhan fungsional dari sistem ini antara lain:

1. kebutuhan admin

- mengelola data pengguna

- mengelola data karya

- mengelola data kategori karya

- mengelola data transaksi

- mengelola data pembayaran

2. kebutuhan kreator

- melihat komentar

- melihat pembayaran

- mengelola data karya

- mengelola data pengguna

3. kebutuhan klien

- mengisi data pengguna

- melihat karya

- melihat kategori karya

- mengisi data transaksi

- melakukan pembayaran

\section{b. Kebutuhan Non-Fungsional}

Kebutuhan non fungsional merupakan jenis kebutuhan yang berisi properti perilaku yang dimiliki oleh sistem. Kebutuhan ini tidak terkait dengan perancangan dan pembangunan sistem, namun dapat mempengaruhi jalannya sistem. Kebutuhan non-fungsional dari sistem ini antara lain:

1. Kebutuhan Perangkat Keras

Kebutuhan perangkat keras digunakan dalam membangun sistem ini antara lain:

- Processor : AMD Dual-Core C60

- Harddisk : 320GB

- RAM : 3GB

2. Kebutuhan Perangkat Lunak

Kebutuhan perangkat lunak yang digunakan dalam membangun sistem ini antara lain:

- Sistem Operasi Windows

- Sublime Text 3

- XAMPP

- MySQL dan 


\subsection{Rancangan Sistem}

Dari hasil analisis kebutuhan, dihasilkan gambaran desain sistem dan perangkat lunak yang akan dihasilkan dari marketplace komunitas grafis tradisional. Strategi dalam tahapan perancangan informasi portofolio pada marketplace ini mengacu pada perancangan berbasis struktural. Data Flow Diagram (DFD) menjelaskan gambaran aliran data dalam sistem. Data flow diagram digunakan untuk menggambarkan dari mana asal data, dan kemana tujuan data yang keluar dari sistem, dimana data disimpan, proses apa yang menghasilkan data tersebut, dan interaksi antara data yang tersimpan, dan proses yang dikenakan pada data tersebut. Context Diagram (DFD Level 0) merupakan diagram yang hanya terdiri dari satu proses yang menggambarkan hubungan antara entitas luar, masukan dan keluaran dari sistem. Pada context diagram terdapat tiga entitas luar (external entity) yang terlibat dalam sistem. Ketiga entitas luar tersebut adalah Admin, Kreator, dan Klien. Context Diagram dapat dilihat pada Gambar 2.

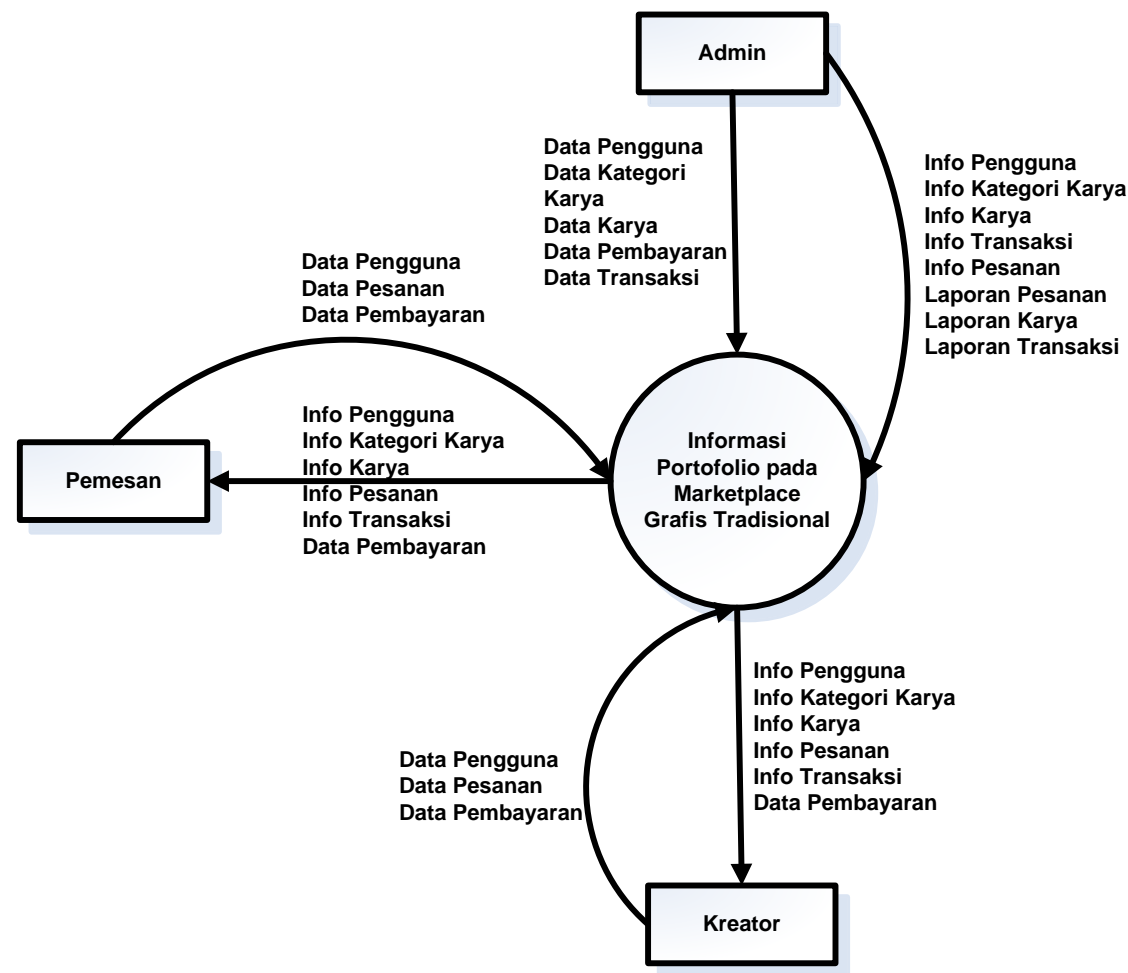

Gambar 3. Contex Diagram pada Sistem

Setelah Data Flow Diagram selanjutnya adalah pembuatan Entity Relationship Diagram (ERD) untuk menggambarkan rancangan data dalam bentuk basis data. Perancangan basis data untuk Implementasi Informasi Portofolio pada Marketplace Grafis Tradisional (Gambar Tangan) ini digambarkan dalam bentuk Entity Relationship Diagram (ERD). Aturan bisnis dalam Entity Relationship Diagram (ERD) untuk Implementasi Informasi Portofolio pada Marketplace Grafis Tradisional (Gambar Tangan) adalah sebagai berikut :

1. Setiap Kreator dapat memiliki banyak karya, sedangkan setiap karya hanya dimiliki oleh satu Kreator.

2. Setiap Klien dapat melakukan banyak pesanan, sedangkan setiap pesanan hanya dapat dilakukan oleh satu Klien.

3. Setiap Admin dapat mengelola banyak transaksi, sedangkan setiap transaksi hanya dapat dilakukan oleh satu Admin.

4. Setiap karya memiliki satu kategori, dan satu kategori dimiliki oleh satu karya.

Entity Relationship Diagram (ERD) untuk Implementasi Informasi Portofolio pada Marketplace Grafis Tradisional (Gambar Tangan) yang terdiri dari entitas pengguna, entitas karya, entitas kategori, entitas pesanan, entitas transaksi, dan entitas pembayaran dengan kardinalitas relasi masing-masing sesuai aturan bisnis yang telah dibuat. Entity Relationship Diagram (ERD) untuk Implementasi Informasi Portofolio pada Marketplace Grafis Tradisional (Gambar Tangan) dapat dilihat pada Gambar 3.

Perancangan yang dihasilkan dari data flow diagram dan entity relationship diagram mengacu kepada kebutuhan dari hasil analisis kebutuhan dan juga disesuaikan dengan informasi portofolio dari kreator grafis tradisional yang akan diimplementasikan pada marketplace yang akan dibuat untuk komunitas grafis tradisional.

Perancangan selanjutnya setelah data flow diagram dan entity relationship diagram adalah perancangan antarmuka dari sistem yang menghasilkan tampilan dari sistem informasi portofolio pada marketplace grafis 
JURNAL MEDIA INFORMATIKA BUDIDARMA

Volume 4, Nomor 3, Juli 2020, Page 666-675

ISSN 2614-5278 (media cetak), ISSN 2548-8368 (media online)

Available Online at https://ejurnal.stmik-budidarma.ac.id/index.php/mib

DOI 10.30865/mib.v4i3.2071

tradisional yang diimplementasikan dengan bahasa pemrograman PHP. Perancangan antarmuka dari sistem digambarkan dalam bentuk hierarki menu dari sistem informasi portofolio pada marketplace grafis tradisional yang dapat dilihat pada Gambar 4.

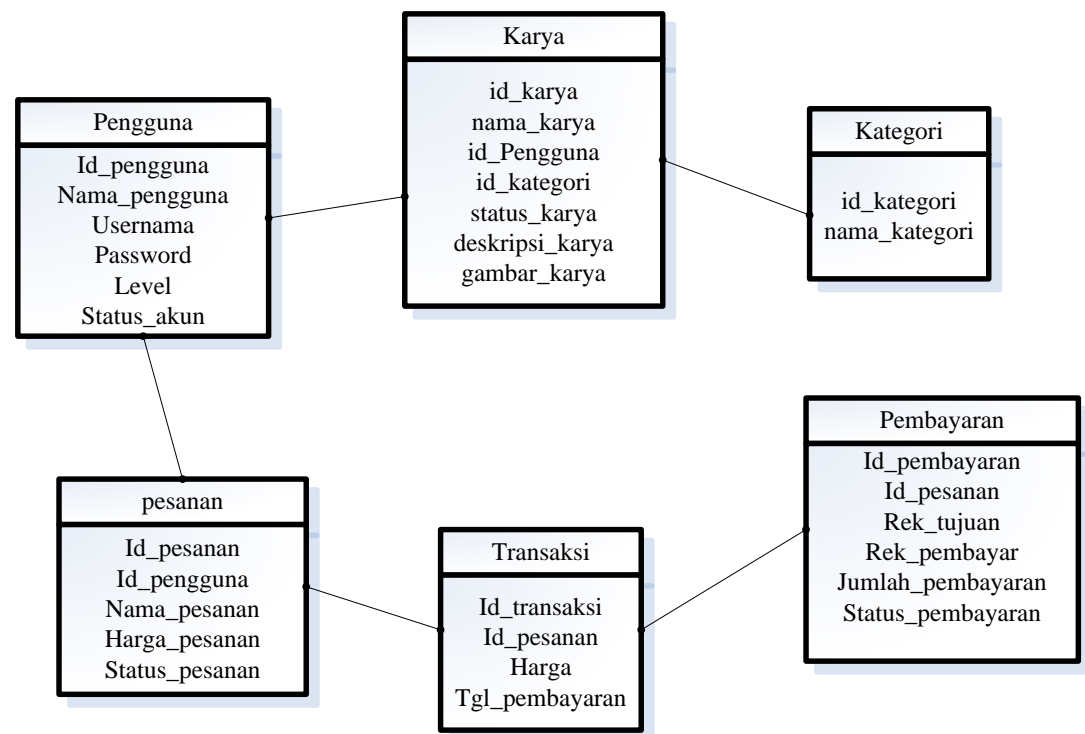

Gambar 4. Entity Relationship Diagram (ERD) pada Sistem

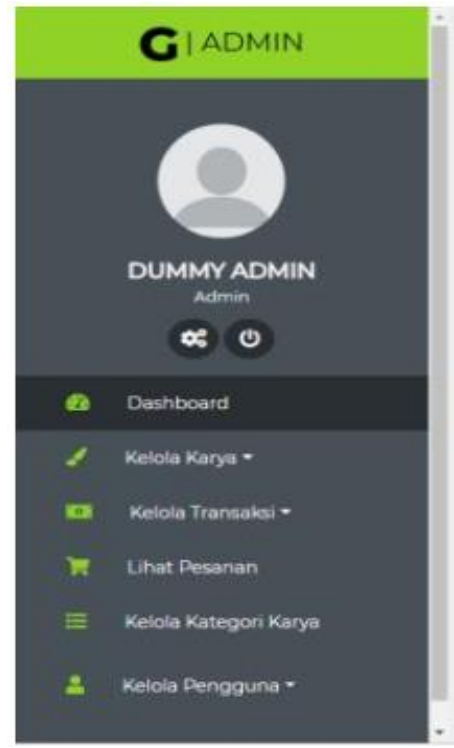

Gambar 5. Hierarki/side menu pada Sistem

\subsection{Implementasi Sistem}

Implementasi antarmuka sistem portofolio pada marketplace grafis tradisional merupakan tampilan antarmuka yang dibuat mengacu pada perancangan antarmuka sistem dengan menerjemahkan perancangan antarmuka sistem dan basis data dalam bahasa pemrograman. Antarmuka sistem dalam pengimplementasian informasi portofolio pada marketplace grafis tradisional disampaikan sebagai berikut.

\section{a. Halaman Beranda}

Pada halaman beranda merupakan implementasi dari perancangan user interface halaman beranda yang menampilkan karya yang telah diunggah Kreator dan diterima oleh Admin. Pada halaman ini terdapat form username dan password untuk melakukan proses login. User memasukkan username dan password agar dapat masuk ke halaman profil sesuai dengan level masing-masing user. Halaman mendaftar akun. Pada halaman ini terdapat form untuk mengisi email, username, password untuk melakukan pendaftaran akun baru. Pengguna yang baru saja mendaftar akan memilih role sesuai dengan tujuan dalam menggunakan sistem. Implementasi halaman beranda user terdapat pada Gambar 6 dan implementasi halaman beranda bagi admin terdapat pada Gambar 7. 


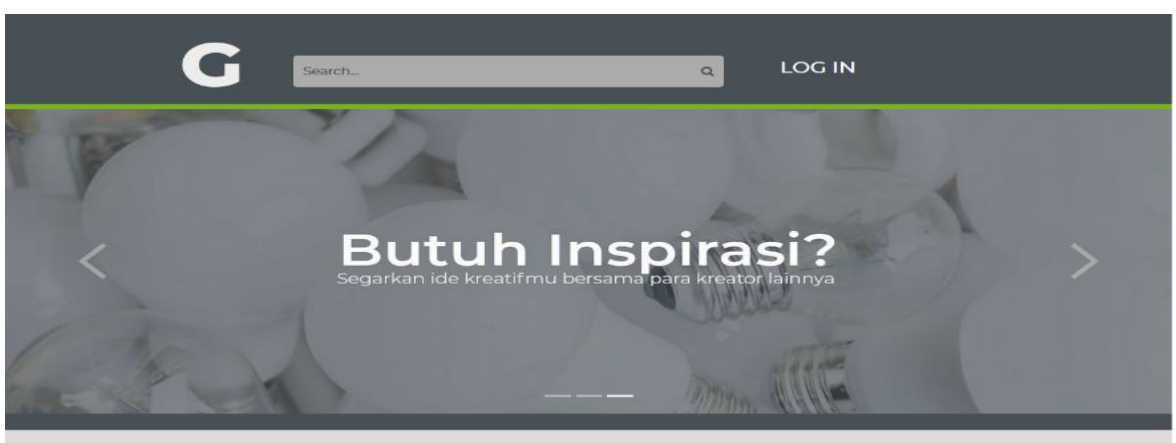

Gambar 6. Implementasi Halaman Beranda User
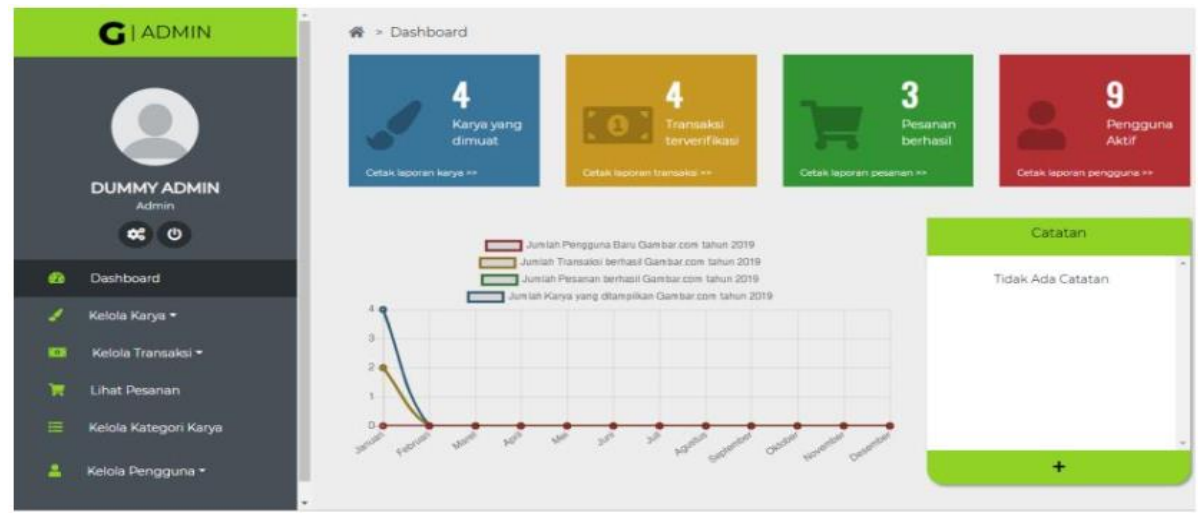

Gambar 7. Implementasi Halaman Beranda Admin

\section{b. Halaman Portofolio Kreator}

Halaman ini merupakan implementasi perancangan user interface halaman portofolio Kreator yang menampilkan profil dari para Kreator. Dalam halaman profil ini merupakan implementasi profil dari masingmasing kreator yang dijadikan sebagai portofolio kreator. Halaman ini menyediakan menu secara spesifik yang memberikan informasi mengenai profil Kreator yang terdiri atas data karya, data pesanan, testimoni dan tentang saya, sehingga klien dapat melihat informasi portofolio dari kreator dan bisa memberikan apresiasi kepada Kreator baik dengan testimoni maupun memberikan like sehingga dapat meningkatkan nilai karya Kreator. Implementasi halaman portofolio Kreator terdapat pada Gambar 8 dan hasil apresiasi/testimoni terdapat pada Gambar 9.

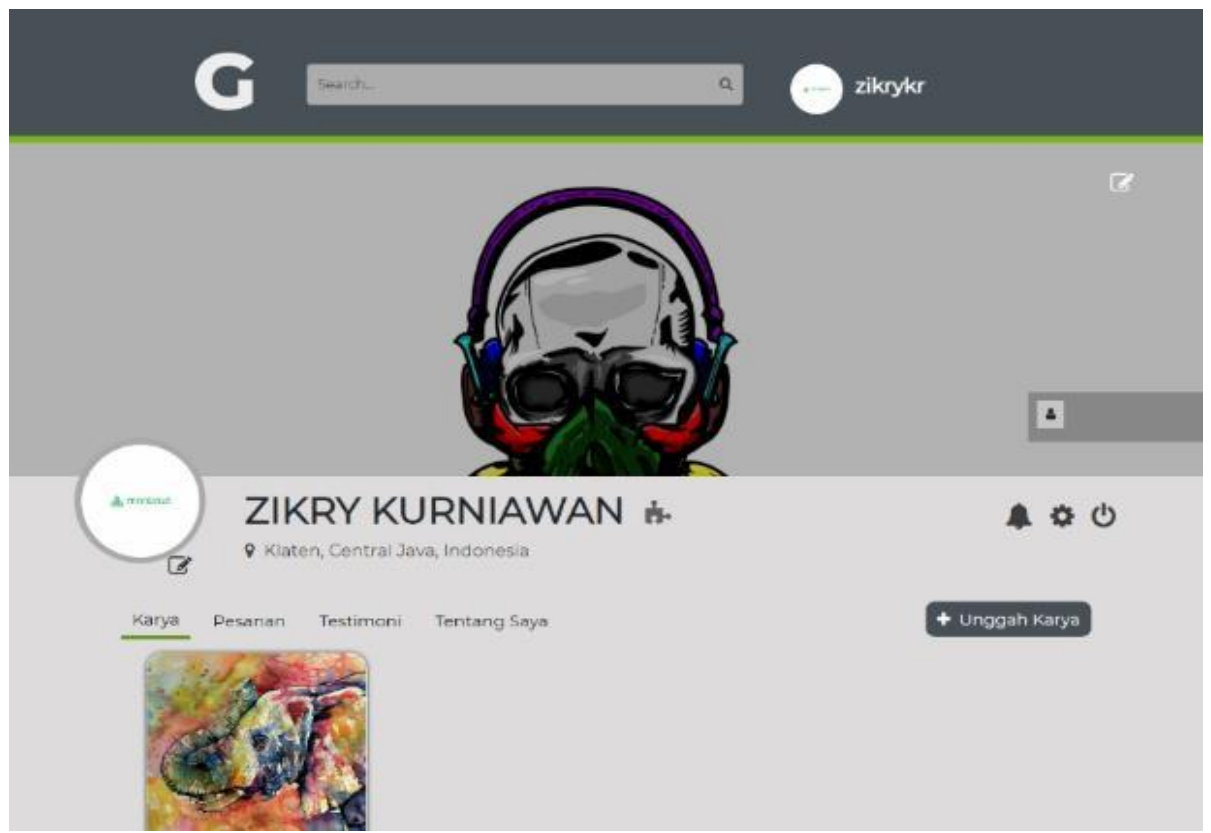

Gambar 8. Implementasi Halaman Portofolio Kreator 
ISSN 2614-5278 (media cetak), ISSN 2548-8368 (media online)

Available Online at https://ejurnal.stmik-budidarma.ac.id/index.php/mib DOI 10.30865/mib.v4i3.2071

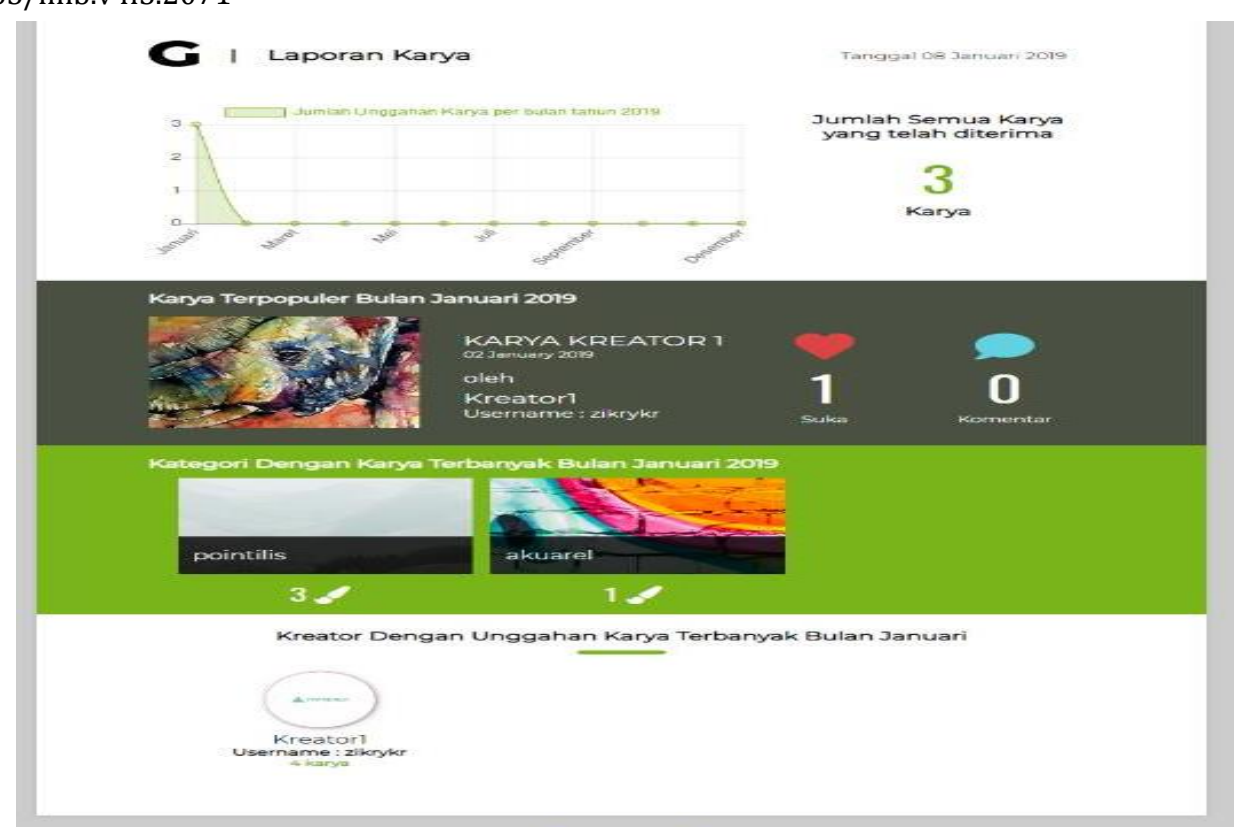

Gambar 9. Implementasi Halaman Hasil Apresiasi/Testimoni

\section{c. Implementasi Halaman Unggah Karya}

Implementasi Halaman Unggah Karya merupakan implementasi perancangan user interface halaman unggah karya yang menampilkan form untuk mengunggah karya oleh para Kreator sehingga dapat ditampilkan dalam halaman portofolio mereka. Kreator dalam mengunggah karya harus diberikan informasi yang jelas mengenai karyanya sehingga klien dapat melihat informasi karya dengan lengkap mulai dari nama karya, kategori karya, deskrisi karya, ukuran, dan informasi apakah karya akan diperjual belikan atau hanya sebagai portofolio saja. Semua karya yang diunggah oleh Kreator dapat diberikan apresiasi oleh klien dan akan ditinjau oleh Admin dari marketplace untuk bisa ditampilkan dalam portofolio Kreator maupun dalam beranda marketplace. Implementasi halaman unggah karya terdapat pada Gambar 10.

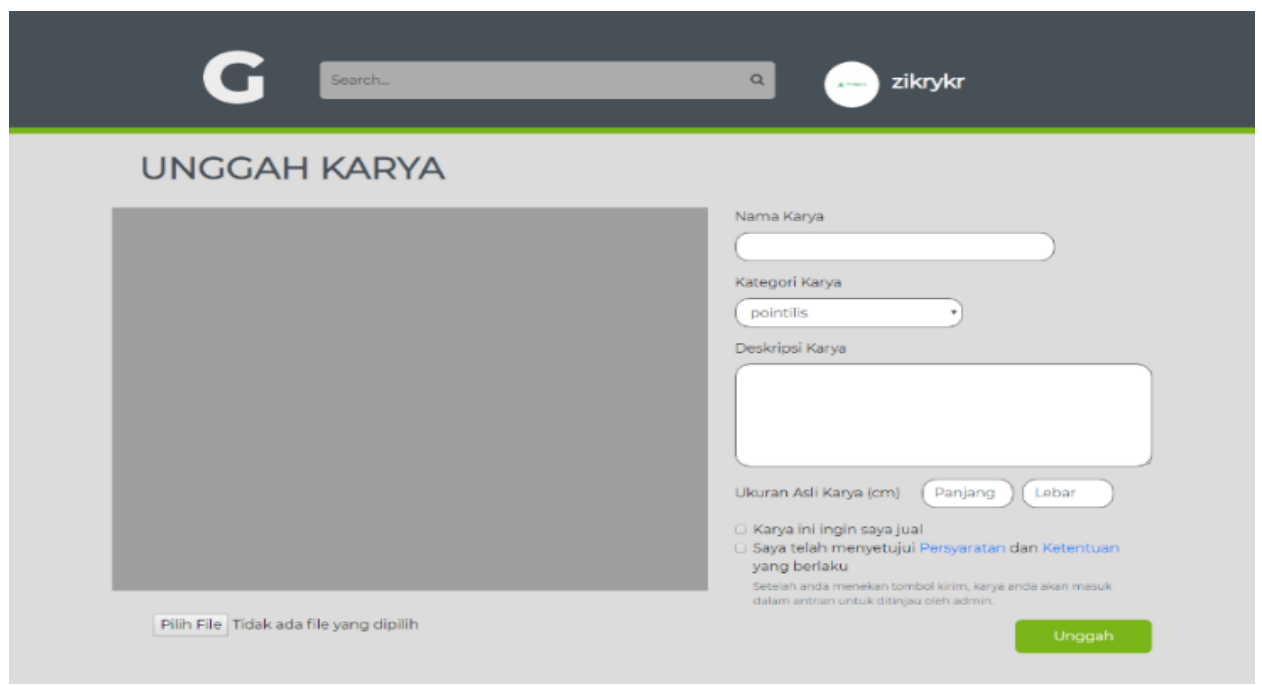

Gambar 10. Implementasi Halaman Unggah Karya

\section{d. Implementasi Halaman Kelola Transaksi}

Halaman ini merupakan implementasi perancangan user interface halaman kelola transaksi yang menampilkan rincian pesanan. Dalam marketplace, klien dapat melakukan proses pemesanan karya dari Kreator tententu yang diminati berdasarkan hasil karya yang Kreator pajang dalam portofolio mereka. Selanjutnya pesanan yang diinputkan klien akan masuk notifikasinya ke admin dan kreator untuk selanjutnya diproses dan dilakukan proses pembayaran oleh klien. Implementasi halaman rincian pesanan terdapat pada Gambar 11. 


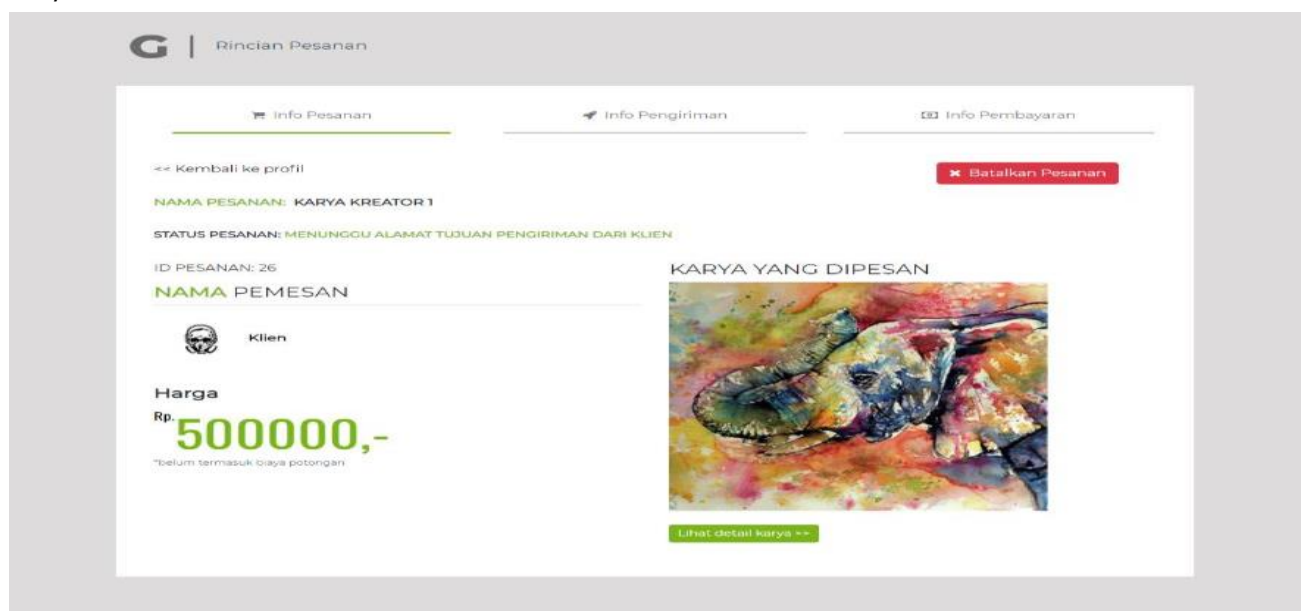

Gambar 11. Implementasi Halaman Rincian Pesanan

\subsection{Pengujian Sistem}

Sistem yang telah dibangun melalui tahap implementasi dan pengujian selanjutnya dilakukan pengujian sistem secara keseluruhan mengacu pada perancangan sistem untuk mengetahui bahwa sistem berjalan dengan baik sesuai dengan perancangan. Pengujian sistem dilakukan dengan menggunakan black box testing yang berdasarkan pada persyaratan fungsional sistem. Hasil pengujian sistem menggunakan black box tesing dapat dilihat pada Tabel 1.

Tabel 1. Hasil Pengujian Sistem

\begin{tabular}{lll}
\hline \multicolumn{1}{c}{ Item Pengujian } & \multicolumn{1}{c}{ Detail Pengujian } & Hasil \\
\hline Form login salah & Memasukkan data login yang salah. & Diterima \\
Form login kosong & Mengosongkan salah satu form login. & Diterima \\
Form login benar & Memasukkan data login yang benar. & Diterima \\
Menampilkan data karya/portofolio & Menampilkan data karya/portofolio & Diterima \\
Menampilkan data pesanan & Menampilkan data pesanan & Diterima \\
Menampilkan data transaksi & Menampilkan data transaksi & Diterima \\
Menampilkan data pembayaran & Menampilkan data pembayaran & Diterima \\
Mengubah status data pembayaran & Mengubah status data pembayaran & Diterima \\
Menampilkan data komentar & Menampilkan data komentar & Diterima \\
Menampilkan data testimoni & Menampilkan data testimoni & Diterima \\
\hline
\end{tabular}

Pengujian terhadap sistem juga dilakukan menggunakan uji MOS (Mean Opinion Score) yang dilakukan berbasis user acceptance test terhadap 10 responden dengan 10 pernyataan terkait aplikasi yang dibangun. Kuisioner dibagikan terhadap 10 pengguna sistem informasi portofolio pada marketplace dengan memberikan bobot penilaian yang dapat dilihat pada Tabel 2 dan hasil pengujian survey yang dilakukan pada masing-masing responden dapat dilihat pada Tabel 3.

Tabel 2. Bobot Penilaian MOS (Mean Opinion Score)

\begin{tabular}{lll}
\hline MOS & Keterangan & Bobot \\
\hline SS & Sangat Setuju & 4 \\
S & Setuju & 3 \\
KS & Kurang Setuju & 2 \\
TS & Tidak Setuju & 1 \\
\hline
\end{tabular}

Tabel 3. Hasil Survey Pengujian Aplikasi

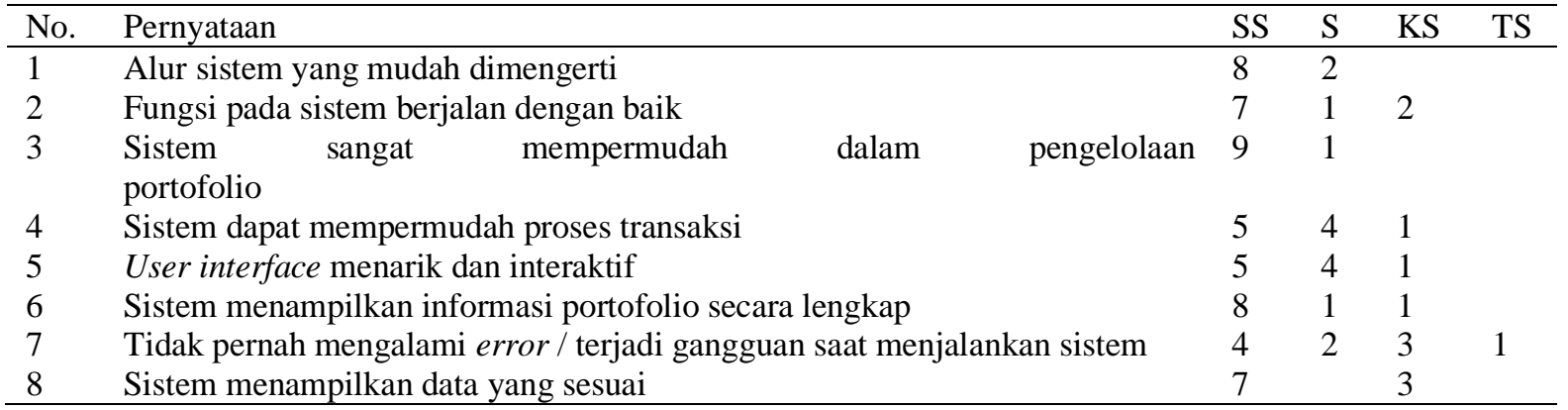


Available Online at https://ejurnal.stmik-budidarma.ac.id/index.php/mib DOI 10.30865/mib.v4i3.2071

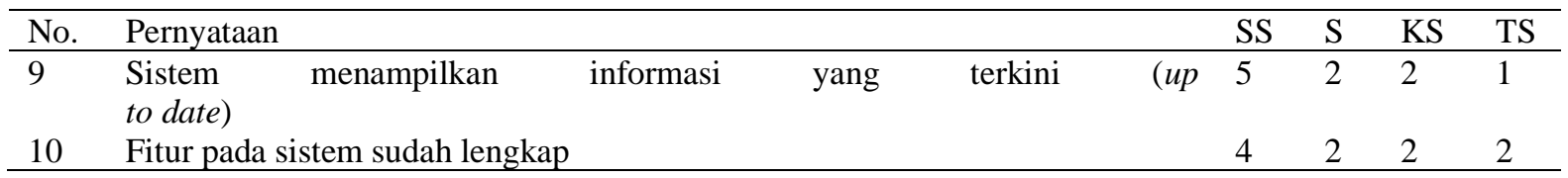

Dari hasil analisa pengujian yang dilakukan dengan sistem berbasis user acceptance test maka nilai MO yang diperoleh diubah ke dalam presentase sebagai berikut :

a. $95 \%$ responden menyatakan alur sistem yang mudah dimengerti.

b. $87.5 \%$ responden menyatakan fungsi pada sistem berjalan dengan baik.

c. $97.5 \%$ responden menyatakan sistem sangat mempermudah dalam pengelolaan portofolio.

d. $85 \%$ responden menyatakan sistem dapat mempermudah proses transaksi.

e. $85 \%$ responden menyatakan user interface menarik dan interaktif.

f. $92.5 \%$ responden menyatakan sistem menampilkan informasi portofolio secara lengkap.

g. $75 \%$ responden menyatakan tidak pernah mengalami error / terjadi gangguan saat menjalankan sistem.

h. $85 \%$ responden menyatakan sistem menampilkan data yang sesuai.

i. $77.5 \%$ responden menyatakan sistem menampilkan informasi yang terkini (up to date).

j. $70 \%$ responden menyatakan fitur pada sistem sudah lengkap.

\section{KESIMPULAN}

Kesimpulan yang diperoleh adalah kebutuhan komunitas grafis tradisional yang sebelumnya mendapat permasalahan dalam memasarkan hasil karyanya secara lebih luas serta membuat portofolio kreator dalam rangka membangun brand dapat dipenuhi dengan pengimplementasian sistem informasi portofolio pada marketplace yang diterapkan pada komunitas grafis tradisional. Dari hasil implementasi informasi portofolio pada marketplace grafis tradisional dapat dijadikan upaya bagi Kreator untuk membangun brand melalui portofolio karyanya secara lebih lengkap serta mampu menangani proses transaksi jual beli karya melalui sistem online. Untuk mendukung pengimplementasian informasi portofolio pada marketplace ini dapat dilakukan penelitian lebih lanjut terkait fitur portofolio seni rupa khususnya grafis tradisional serta pemenuhan fitur-fitur lain yang disesuaikan dengan kebutuhan dari komunitas grafis tradisional pada marketplace yang telah dibuat.

\section{REFERENCES}

[1] Marco R, Bernadheta TPN. 2018.Analisis Sistem Informasi E-Marketplace Pada Usaha Kecil Menengah (UKM) Kerajinan Bambu Dusun Brajan . Jurnal Ilmiah DASI. Vol. 18. No. 2. Hlm.48-53. ISSN: 1411-3201.

[2] Silaen R. 2019. Peran Teknologi Dalam Industri Kreatif Indonesia.Tersedia: https://www.academia.edu/3823751/PERAN_TEKNOLOGI_DALAM_INDUSTRI_KREATIF_INDONESIA [20 Februari 2020]

[3] Nugrahani R. 2014. Portal Portofolio : Media Alternatif Untuk Menjembatani Kebutuhan Lembaga Pendidikan DKV Dan Industri. Vol. Viii No. 2.

[4] Yustiani R,Yunanto R.2017.Peran Marketplace sebagai alternatif Bisnis di Era Teknologi Informasi. Jurnal Ilmiah Komputer dan Informatika, Vol. 6 No.. ISSN : 2089-9033.

[5] Departemen Perdagangan Republik Indonesia. 2009. Studi Industri Kreatif Indonesia 2009 Update.

[6] Nuriyanti W.2019.Peran Media Sosial Dalam Perkembangan Dunia Kreatif. Jurnal Sosio e-kons. Volume 11. No. 2. Hal 101-107.

[7] Rahman F, Mawardi MK..2017.Strategi Umkm Dalam Membangun Brand Toko Online Di Marketplace. Jurnal Administrasi Bisnis (Jab).Vol. 53 No. 1. Hal 39-48.

[8] Mahanal. 2007. Portofolio sebagai Asesmen Otentik. Bandung: Alfabeta

[9] Rusdi F.,Sukendro Gg.2018. Analisis Industri Kreatif Dalam Memanfaatkan Identitas Kota Melalui Media Baru. Jurnal Komunikasi. Vol. 10. No. 1. Hal $95-102$

[10] Apriadi D.,Saputra AY. 2017. E-Commerce Berbasis Marketplace Dalam Upaya Mempersingkat Distribusi Penjualan Hasil Pertanian. Jurnal Rekayasa Sistem dan Teknologi Informasi. Vol. 1 No. 2. Hal 131 - 136

[11] Irawan F. 2014. Online Portfolio Sebagai Media Personal Branding Desainer Grafis. Jurnal Skripsi. Universitas Brawijaya Malang.

[12] Sofwan H, Toriq I. 2018. Peran Media Digital Dalam Perkembangan Industri Kreatif. Prosiding Festival Riset Ilmiah Manajemen Dan Akuntansi. Hal 676-681.

[13] Tokopedia.(2019). Brand Asset. Diakses pada 20 Februari 2020 tersedia: https://www.Tokopedia.com/brand-asset [20 Februari 2020]

[14] Hutauruk BD, dkk.2018.Analisis Dan Perancangan Aplikasi Marketplace Cinderamata Khas Batak Berbasis Andoid. Jurnal Methodika. Vol.3. No.1.Hal 242-246.

[15] Andrean M., dkk. 2017.Perancangan dan Implementasi Sistem Informasi E-Marketplace untuk Katering. Jurnal Teknologi Informasia. Vol.5. No.2.Hal 294-303.

[16] Imam R., dkk.2018.Perancangan Sistem Informasi E-Marketplace Original Clothing Indonesia Berbasis Web. Jurnal Jumantaka.Vol. 1. No.1.Hal 161-170.

[17] Pressman RS. 2010. Rekayasa Perangkat Lunak Pendekatan Praktis. Yogyakarta: Penerbit Andi. 